\title{
Grundtvig-Studier Ig62
}

der udsendes af Grundtvig-Selskabet af 1947, bringer anden del af bibliotekar fens A. Nielsens store afhandling om Grundtvig og Gisselfeld, der især koncentrerer sig om Grundtvigs næsten fuldførte, men aldrig trykte biografi af lensgreve C. C. S. Danneskiold-Samsøe: »Blik paa Grev Danneskiolds Liv« samt Grundtvigs store mindedigt »Gissel-Feld eller Grev Danneskiolds Efter-Mæle paa Rim«. I sin analyse påviser afhandlingens forfatter digtets nære forbindelse med »Nyaas-Morgen $\ll$.

Lektor, dr. phil. William Michelsen, Roskilde, offentliggør sin opposition ved dr. philos. Sig. Aa. Aarnes's disputats om »Historieskrivning og livssyn hos Grundtvig «. Aarbogen indeholder desuden anmeldelser ved domprovst, dr. theol. Henning Høirup, Viborg, og pastor K. E. Bugge, København, samt engelsk resumé ved dr. Noëlle Davies og en fortegnelse over Grundtvig-litteraturen 1960 ved cand. mag. Steen fohansen, København.

Tidligere udkom:

Grundtvig-Studier I 948. Gyldendal. I I 6 sider. Grundtvig-Studier I 949. Gyldendal. I I 2 sider. Grundtvig-Studier I 950. Gyldendal. I 12 sider. Grundtvig-Studier 1951. Gyldendal. I 32 sider. Grundtvig-Studier 1952. Gyldendal. I 08 sider. Grundtvig-Studier I 953. Gyldendal. I 28 sider. Grundtvig-Studier 1954. Gyldendal. I 6 sider. Grundtvig-Studier 1955. Gyldendal. I 20 sider. Grundtvig-Studier i 956 . Gyldendal. i 6 sider. Grundtvig-Studier 1957. Gyldendal. I 32 sider. Grundtvig-Studier 1958. Gyldendal. I 24 sider. Grundtvig-Studier 1959. Gyldendal. I 24 sider. Grundtvig-Studier 1960. Gyldendal. 92 sider. Grundtvig-Studier i 96 I. Gyldendal. I 22 sider.

I serien Skrifter udgivet af Grundtvig-Selskabet er hidtil udkommet:

I. Henning Hoirup: Grundtvigs Syn paa Tro og Erkendelse. Gyldendal I 949.420 sider.

II. Helge Toldberg: Grundtvigs symbolverden. Gyldendal i950. XII + 356 sider.

III. Magnus Stevns: Fra Grundtvigs Salmevarksted. Udgivet af Henning Høirup og Steen Johansen. Gyldendal I 950.

IV. Villiam Gronbak: Psykologiske tanker og teorier hos Grundtvig. Gyldendal I951. I92 sider.

V. Carl Weltzer: Grundtvig og Søren Kierkegaard. Gyldendal 1952. 96 sider.

VI. William Michelsen: Tilblivelsen af Grundtvigs historiesyn. Gyldendal 1954. 368 sider.

VII. Henning Hoirup: Fra doden til livet, Grundtvigs tanker og liv og dod. Gyldendal I 954 . I 12 sider.

VIII. Niels Kofoed: Grundtvig som selvbiograf. Gyldendal 1954. I 36 sider.

IX. William Michelsen: Den salsomme forvandling i N.F. S. Grundtvigs liv. Gyldendal 1956. 288 sider.

X. N.F.S. Grundtvig: Taler paa Marielyst Højskole 1856-7 I, udgivet af Steen fohansen. Gyldendal i 956. I 6 sider.

XI. Harry Aronson: Mänskligt och kristet. Eu studie i Grundtvigs teologi. Bonnier I96o. 3 I 2 sider.

XII. Sigurd Aa. Aarnes: Historieskrivning og livssyn hos Grundtvig. Oslo I 962.

Til Grundtvig-Selskabet er overgået:

II a. Helge Toldberg: Grundtvig som filolog. G. E. C. Gad 1946. 152 sider. 